символы; аббревиатуры. В этом исследовании подробно освещена специфика скобок и цифр как интегральных модусов массмедийной среды.

Определены их семантические и структурные особенности, идентифицирована функциональная нагрузка, обоснованно их роль и назначение в современном англоязычном массмедийном коммуникативном пространстве. Кроме традиционного использования круглых скобок как знаков препинания в составе текста, которые дополнительно объясняют содержание, уточняют сказанное вне текста в скобках, активно привлекают квадратные, фигурные, атипичные видоизмененные (контекстуально зависимые).

Кроме типичных функций, скобки выполняют и ряд атипичных будучи разными по размерам, форме и количественному составу, в частности: уточняющую, лаконичную, дейктичную, содержательно-разветвительную, аттрактивную, содержательно-выделительную, акцентирующую внимание, структурующую, компрессионную, а также указывают на инициальную и финальную часть текста.

Установлено, что в англоязычном массмедийном коммуникативном пространстве цифры используют вместо лексем, графем и морфем. Они компрессируют количество традиционных графических элементов, входящих в состав одной лексемы. Бывают случаи, когда вместо словесного модуса используют цифровой, который выполняет роль лексемы. Цифровые модуса также бывают различных форм и размеров и имеют разные цветовые окраски. Выявлено, что наиболее распространенным является привлечение цифр четыре и два, которые замещают различные лексемы (for, four, two, to т.д.).

Ключевые слова: масс-медиа, коммуникативное пространство, скобки, цифры, функция.

Makaryk Larysa. The Structure, Semantics and Functions of Brackets and Numerals in the Contemporary English-Language Mass-Media Communicative Space. In this paper, as its title indicates, an analysis is presented of brackets and numerals, two specific non-verbal items in the general category of non-verbal and paraverbal elements which exist in the modern English-language mass media communicative space. By way of background, it could be mentioned that these items have been singled out from the overall category which may be termed "Non-pictographic and non-photographic elements" also includes other punctuation marks, as well as diacritical marks, typographic and other auxiliary signs, mathematical symbols, and abbreviations. As noted above, this study focuses in detail on the specific features of numerals and various types of brackets as integral modes within the media environment.

Their semantic and structural features are outlined, their functions are identified, and their role and purpose in the modern English-language mass-media communicative space are substantiated. The customary textual function of parentheses and square brackets as punctuation marks has been to enclose explanatory information regarding the content of the text, or to clarify what is expressed outside the parenthesized text. However, in addition to these features and functions, reference can be made to braces and 'curly' and atypical modified (contextually dependent) brackets, which can perform non-traditional functions through differences in size, shape and quantitative composition, being deictic, content-branching, focusing, structuring, and compressive and clarificatory.

Our study also demonstrated that in the English-language mass media communicative space, numerals may carry out the function of lexemes, graphemes and morphemes. They can be compressive in that they make it possible to reduce the number of traditional graphic elements that are part of a single lexeme. There are cases where a numeric character can act as a lexeme when used in place of the verbal expression. (This occurs most frequently with the numbers 2 and 4, which can take the place of the verbal units 'two', 'to', and 'too', and of 'four', 'fore', and 'for', as well as of syllables within longer words which contain these phonemes. These functions of these numerals can also be expanded by the use of differing shapes, sizes and colors.

Key words: mass-media, communicative space, brackets, numbers, function.

DOI: https://doi.org/10.32782/2410-0927-2020-12-22

УДК 811.111 '42

Наталія Одарчук, Тетяна Мірончук

\title{
TED-конференції - платформа для англомовного мотиваційного дискурсу
}

Останнім часом TED-конференції стали однією 3 найпопулярніших платформ у світовій спільноті для поширення ідей, гідних наслідування. Виголошені англійською мовою промови, присвячені мотивації, посідають чільне місце серед численних виступів науковців, медиків, програмістів, музикантів, просто пересічних громадян, які готові поділитися ідеєю, вартою поширення. У статті піддані аналізу виступи ораторів TED-конференцій 3 метою доведення їхньої мотиваційної спрямованості. Для реалізації мети спершу з'ясована семантика поняття мотивації, а далі на основі відібраних промов декількох спікерів із платформи TED проаналізоване семантичне наповнення їхньго тексту. Задля встановлення найуживаніших лексичних одиниць створене семантичне ядро кожного виступу. Виокремлення й аналіз семантичного ядра промов дозволяє переконатися в тому, що найуживаніші лексичні одиниці

(C) Одарчук Н., Мірончук T., 2020 
відображають тему виступу, спікер будує свою промову навколо єдиної ідеї, що і передбачено вимогами організаторів TED-конференцій.

Зроблений висновок про те, що мотивація як феномен, при якому діяльність однісї людини (чи групи людей) регулюється іншою, враховуючи ту чи ту потребу, є набором цілеспрямованих дій, пов'язаних з інтенцією мовця вплинути на співрозмовника і певним чином змінити або зберегти вже існуючий стан речей. Виступи на конференціях TED мають інформативно-персуазивно-спонукальний характер. 3 одного боку, спікерові важливо повідомити фактичний матеріал (факти, ідеї, результати). Проте важливіше для нього - вплинути на слухача, переконати в прийнятності своєї ідеї, викликати емоційну рефлексію в аудиторії, добитися того, щоб виступ актуалізував проблему, надихнув, змотивував до подальших дій задля іï розв'язання. Здійснюючи когнітивнокомунікативну діяльність через TED talks за допомогою стратегій інформування, переконання і спонукання, промовці впливають відповідно на різні сфери свідомості: раціональне мислення, емоції та волевиявлення. В результаті цього вони творять мотиваційний дискурс, суб'єктами якого є вони самі в ролі ораторів та аудиторія - в ролі реципієнтів.

Ключові слова: мотивація, мотиваційний дискурс, TED-конференція, стратегія, семантичне ядро, лексема.

Вступ. Потреба у вмотивованій, цілеспрямованій особистості як ніколи раніше гостро постає в постмодерному суспільстві. Це зумовлене, по-перше, ритмічністю, напруженістю сьогодення, постійними викликами і боротьбою “за місце під сонцем”, по-друге - гострою необхідністю для представників одного прошарку соціуму успішно виконувати плани, вкладатися в дедлайни, іншого ж - забезпечити своє оточення саме такими працівниками. Тому на часі замислитися над новими формами, методами, способами як внутрішньої самомотивації, так і зовнішньої - заохочення інших до активних змін, до наслідування прикладу, до готовності толерувати хаотичний світ тощо. Позаяк грунтовний науковий підхід до справи забезпечує вищий відсоток успіху, то мотивація як поняття і як феномен стає об'єктом дослідження різних дисциплін, лінгвістики зокрема. Все вищесказане дозволяє стверджувати, що наукова розвідка не позбавлена актуальності і ставить за мету проаналізувати виступи під час TED-конференцій і довести їхню мотиваційну спрямованість. Для реалізації мети спершу з'ясуємо семантику поняття мотивації, а далі на основі трьох промов, відібраних із платформи TED із різних сфер (Entertainment, Business, Environment), проаналізуємо їхнє семантичне наповнення, створивши семантичне ядро кожного виступу задля встановлення найуживаніших лексичних одиниць, а також визначимо, якими стратегіями користуються промовці для мотивування аудиторії.

Аналіз попередніх досліджень. Первинно мотивація була об’єктом і предметом психологічних розвідок (А. Маслоу із відомою пірамідою, що відображає ієрархію потреб людини, двофакторна теорія мотивації Ф. Герцберга, теорія набутих потреб Д. МакКлелланда, соціопсихічна теорія мотивації Е. Мейо, теорія X та Y Д. МакГрегора, комплексна теорія-модель Портнера-Лоулера та багато інших [14]). Сучасні вітчизняні психологи-науковці не припиняють вивчати явище мотивації (О. Захарко - внутрішню мотивацію індивіда, Л. М. Янович поведінковий аспект тощо), проте все частіше мотивація стає об'єктом дослідження інших гуманітарних дисциплін.

Педагогіка й методика запозичила явище мотивації для з'ясування факторів успішного навчання школярів та студентів, соціологія застосовує його в адміністративній та управлінській сфері для відпрацювання моделі керівник - підлеглий. Для лінгвістики, зокрема вітчизняної, поняття мотивації теж не нове, досліджують його передовсім із позиції семасіології. О. Селіванова класифікувала й описала типи мотивації залежно від статусу мотиватора: пропозиційно-диктумна, асоціативно-термінальна, інтеграційно-порівняльна, модусна, змішана, а також запропонувала нову концепцію мотиваційних процесів [9, с. 483-484], Т. Р. Кияк проаналізував різні види мотивованості лексичних одиниць, запропонувавши їхні кількісні і якісні характеристики, О.Крижко вивчає це явище в словотвірному, номінативному та лінгвокогнітивному аспектах [5].

Своєрідним проривом у прагматичному розумінні мотивації стала праця Є. Селівана "Three Roles of Language in Motivation Theory”, в якій автор досліджує використання мотиваційного мовлення менеджерами, що грунтується на декількох важливих пресупозиціях. Перша: те, що каже менеджер, безпосередньо впливає на мотивацію працівника; друга: комунікація менеджера окреслюється трьома мовленнєвими актами: 1) тими, які знижують рівень невпевненості працівників і підвищують їхні знання (локутивний акт); 2) тими, які імпліцитно знову 
підтверджують відчуття власної значимості працівників (іллокутивний акт); 3) тими, які сприятимуть конструюванню когнітивних схем, що скеровуватимуть працівника у виконанні його роботи (перлокутивний акт). Третя пресупозиція полягає в тому, що сучасні мотиваційні теорії фокусуються виключно на мовленнєвих актах, вимовлених менеджерами з метою зменшення невпевненості працівників. Є. Селіван стверджує, що чим різноманітніші мовні засоби залучає менеджер, тим більша ймовірність, що він позитивно вплине на мотивацію підлеглого [11]. Висунута теорія науково доводить вагу слова у мотивуванні співрозмовника до певних дій.

Результати та дискусії. Сучасний міждисциплінарний підхід доводить можливість дослідження певного поняття чи феномену на стику наук, поєднуючи методики декількох галузей, залучаючи здобутки фахівців різних сфер. В.Климчук у своїй монографії “Мотиваційний дискурс особистості: на шляху до соціальної психології мотивації” тлумачить мотиваційні процеси як такі, що перебувають у стані постійного дискурсивного конструювання. Вони занурені в різного роду суспільні дискурси, а також самі проявляються у власних, персоналізованих дискурсах, тому можуть чинити вплив на мотиваційні дискурси інших. В. Климчук стверджує, що психологія мотивації сьогодні заглиблюється до інтеракційного простору [4, с. 4], конференції TED є не що інше як інтеракція між спікером і аудиторією, в процесі якої твориться мотиваційний дискурс.

TED talks (Technology Entertainment Design) - щорічна конференція, що проводиться в США 31984 року. Місія конференції полягає в поширенні унікальних ідей (Ideas worth spreading - “ідеї, гідні поширення”). Назва “Technology, Entertainment and Design” відображає лише умовний перелік тем, якими цікавиться спільнота. Актуальний перелік цих тем налічує більше ніж 438 найменувань (Addiction, Biotech, Dark matter, Ebola, Immigration, Marine biology, Nuclear energy, Pandemic, Religion, Slavery, Terrorism, Youth тощо). Одна промова може торкатися декількох тем, проте вона пропонує аудиторії лише одну ідею для втілення в соціальну практику. Діяльність TED-спільноти з кожним роком активізується, що приводить до зростання кількості конференцій та до розширення обсягу контенту, а це - до збільшення кількості мотиваційних промов. Всезростаючий інтерес суспільства до TED-спільноти як до джерела цікавих та корисних ідей виявляється в тому, що остання постійно віднаходить нові засоби розповсюдження промов та ідей, які вони несуть [12]. Погоджуючись із твердженням Л. С. Виготського, що будь-яка мовна діяльність - умотивована [13], спробуємо довести мотиваційний характер виступів спікерів на TED-конференціях.

Інтерес до мотивації як до неоднозначного явища соціального спілкування індивідів далеко не новий, він сягає античних часів. Ще Аристотель, проводячи аналіз структури людської діяльності, назвав один з іiї елементів телеологічною причиною (від грец. teleos - той, хто досягає мети). Останню він розумів як внутрішню зацікавленість, потребу, мету суб'єкта діяльності, прагнення до чого є внутрішнім фактором сприйняття зовнішнього примусу, в нашому випадкупевного мотиваційного висловлювання. В академічному тлумачному словнику української мови “мотивація” визначається як “сукупність мотивів, доказів для обгрунтування чогось; мотивування" [10]. Оксфордський словник англійської мови подає таку дефініцію терміна: a reason or reasons for acting or behaving in a particular way; desire or willingness to do something; enthusiasm [7]. Отже, маючи в своїй основі лексему “мотив”, що позначає потребу, яка вимагає задоволення, мотиваціяце причина людських вчинків, охота, бажання. Останні можуть виникати під впливом культури, суспільства, способу життя тощо чи навіть бути внутрішньо притаманні. Мотивація - це рух до певної поведінки, це те, що змушує людину хотіти повторювати іiі, це сила, яка діє часто незалежно від волі індивіда. Мотивація є результатом взаємодії свідомих і несвідомих факторів, а тому розрізняють зовнішню і внутрішню мотивацію, де перша - натхнення від інших членів соціуму, від подій, а друга йде зсередини. На позначення цих видів мотивації у психології i педагогіці вживаються терміни екстринсивна й інтринсивна мотивація відповідно [8]. Незалежно від джерела походження мотивація завжди рухає людину вперед.

Спробуємо довести, що з платформи TED промовці творять саме мотиваційний дискурс. Беручи за основу твердження В. Климчука, розуміємо мотиваційний дискурс як: 
- подію: особистісний вербальний процес, у якому або собі, або іншим пояснюються мотиваційні конструкції;

- продукт: текст (письмовий, усний), який є результатом конструювання мотивації, наповнений розмовною мовою чи термінами, риторичними запитаннями, повтором ключових слів, узагальненнями, спілкуванням з публікою, закликами;

- тип: дискурс, який містить мотиваційний компонент (різного ступеня вираження) у вигляді безпосередніх вербальних і невербалізованих мотиваційних конструкцій або ж їх опосередкованих описів [4, с. 113].

Виходячи з тези, що ніщо не має такої сили, як потужна ідея, що здатна змінювати світ на краще, пробуджувати бажання руху та розвитку, впливу на людей, на їх сприйняття світу та переконання, організатори TED-конференцій вбачають свою місію в пошуку людей, які можуть генерувати ідеї та передавати їх найширшій зацікавленій аудиторії. Матеріал, розповсюджений у межах конференцій TED, уважаємо релевантним для дослідження процесу мотивації, об'єктом якої є корисна ідея. За допомогою неї вирішується певна нагальна проблема. За форматом виступу спікер як учасник TED-спільноти будує свою промову навколо єдиної ідеї, яку він намагається донести до слухачів. За рекомендацією куратора TED-конференції Кріса Андерсона виступ на сцені має тривати не більше 18 хвилин [12], проте непоодинокими є випадки перевищення мовцями цього часового обмеження.

Виступ на конференціях TED має інформативно-персуазивно-спонукальний характер. 3 одного боку, спікеру важливо повідомити фактичний матеріал (факти, ідеї, результати, схеми). Проте важливіше - вплинути на слухача, переконати в прийнятності свого месиджу, викликати емоційну рефлексію в аудиторії, добитися того, щоб виступ актуалізував проблему, надихнув, змотивував до подальших дій задля іiі розв'язання [3]. Це дозволяє стверджувати, що, здійснюючи когнітивно-комунікативну діяльність через TED talks, промовці творять мотиваційний дискурс, суб'єктами якого є вони самі (оратори) та реципієнти (аудиторія). Погоджуємося із думкою Д. М. Кайсіної, що, впливаючи на різні сфери свідомості: раціональне мислення, емоції та волевиявлення - промовці застосовують у цьому виді дискурсу стратегії трьох типів: інформування, переконання і спонукання [3, с. 5]. На основі трьох відібраних промов продемонструємо, як працюють ці стратегії.

Для з'ясування семантичного наповнення мотиваційних промов ми виявляли семантичне ядро тексту виступу за допомогою комп'ютерних програм інтелектуального аналізу текстів Text mining. Слід зазначити, що кожен відеоролик супроводжується скриптом, і це полегшує роботу iз текстом. Серед різних напрямів TED talks із банку відеороликів у групі Entertainment було обрано промову Аніти Коллінз TED-Ed "How playing an instrument benefits your brain" [2]. Вибору цього та інших відеороликів для лінгвістичного аналізу сприяла велика кількість переглядів на платформі TED.

Доктор Аніта Коллінз - педагог, музикант і дослідниця в галузі розвитку мозку та навчання музики. Використовуючи стратегію інформування, у свойй пристрасній промові авторка доводить, який позитивний вплив має музика на функції мозку: коли людина слухає музику, декілька відділів мозку стають набагато активнішими, вони спалахують, як феєрверки. Гра на музичних інструментах супроводжується тренуванням мозку, що має довгострокові позитивні наслідки.

Семантичне ядро промови "How playing an instrument benefits your brain"

\begin{tabular}{|l|c|c|}
\hline \multicolumn{1}{|c|}{ Слово } & Кількість & Частота, \% \\
\hline brain & 19 & 2.74 \\
\hline music & 15 & 2.16 \\
\hline play & 7 & 1.01 \\
\hline musician & 6 & 0.87 \\
\hline our & 6 & 0.87 \\
\hline activity & 5 & 0.72 \\
\hline function & 5 & 0.72 \\
\hline
\end{tabular}




\begin{tabular}{|l|c|c|}
\hline brain areas & 5 & $0.72 / 1.44$ \\
\hline playing music & 5 & $0.72 / 1.44$ \\
\hline other & 5 & 0.72 \\
\hline tag & 5 & 0.72 \\
\hline when & 5 & 0.72 \\
\hline neuroscientist & 4 & 0.58 \\
\hline all & 4 & 0.58 \\
\hline instrument & 4 & 0.58 \\
\hline memory & 4 & 0.58 \\
\hline more & 4 & 0.58 \\
\hline multiple & 4 & 0.58 \\
\hline
\end{tabular}

Проаналізувавши семантичне ядро промови "How playing an instrument benefits your brain”, можемо зробити висновок, що ораторка використовує найчастіше такі слова: brain, music, play, musician, activity, function. Вони дають можливість засвідчити унікальність впливу музики на роботу нашого (our) мозку під час гри на музичних інструментах. Для переконливості щодо позитивного впливу музичних інструментів на розвиток нашої розумової активності спікерка вдається до вживання таких біологічних і медичних термінів: brain areas, activity, music, function, memory, multiple, neuroscientist:

"Playing a musical instrument engages practically every area of the brain at once, especially the visual, auditory, and motor cortices. As with any other workout, disciplined, structured practice in playing music strengthens those brain functions, allowing us to apply that strength to other activities" [2].

Задля підсилення переконливості своїх тверджень ораторка посилається на дослідження нейрологів, які науково довели неспростовність іiі аргументів:

"Neuroscientists have explored these issues, and have found that the artistic and aesthetic aspects of learning to play a musical instrument are different from any other activity studied, including other arts. And several randomized studies of participants, who showed the same levels of cognitive function and neural processing at the start, found that those who were exposed to a period of music learning showed enhancement in multiple brain areas, compared to the others" [2].

Наступною промовою для аналізу ми обрали виступ Метта Малленвега “Why working from home is good for business" (Matt Mullenweg) [6] зі сфери Business для того, щоб довести, що мотивація присутня у виступах, організованих навколо різноманітних тем.

Метт Малленвег є співзасновником платформи для блогів з відкритим кодом WordPress, найпопулярнішої видавничої платформи в Інтернеті, та засновником і генеральним директором компанії Automattic. Оскільки популярність віддаленої роботи невпинно продовжує зростати, працівники сьогодні можуть віртуально взаємодіяти з різними містами та навіть країнами в межах кількох часових поясів. Як це змінює динаміку компанії? I як можна переконатися, що всі робітники як в офісі, так і вдома, відчувають себе пов'язаними? Метт Малленвег, співзасновник Wordpress та генеральний директор компанії Automattic (яка має 100-відсоткову розподілену робочу силу), ділиться своїми секретами. Ця промова заснована на досвіді роботи ВордПрес від початку заснування до сьогодення.

Семантичне ядро промови “Why working from home is good for business"

\begin{tabular}{|l|c|c|}
\hline \multicolumn{1}{|c|}{ Слово } & Кількість & Частота, $\%$ \\
\hline can & 14 & 1.48 \\
\hline work & 12 & 1.27 \\
\hline distributed & 10 & 1.06 \\
\hline company & 9 & 0.95 \\
\hline together & 6 & 0.64 \\
\hline office & 5 & 0.53 \\
\hline there & 5 & 0.53 \\
\hline this & 5 & 0.53 \\
\hline
\end{tabular}




\begin{tabular}{|l|l|l|}
\hline when & 5 & 0.53 \\
\hline about & 4 & 0.42 \\
\hline different & 4 & 0.42 \\
\hline everyone & 4 & 0.42 \\
\hline first & 4 & 0.42 \\
\hline live & 4 & 0.42 \\
\hline make & 4 & 0.42 \\
\hline thing & 4 & 0.42 \\
\hline week & 4 & 0.42 \\
\hline
\end{tabular}

Таблиця засвідчує такі найуживаніші лексеми: work, distributed, company, office, everyone, live, week, які автор використовує, щоб описати буденну рутину в офісних приміщеннях та протиставити іï віддаленій роботі. Також автор вдається до частого використання дейктиків there та this для порівняння двох видів діяльності та щоб вказати на їх основні відмінності. Модальне дієслово can, що має найбільшу кількість слововживань, ще раз доводить можливість запровадження такої форми організації праці, яку спікер називає distributed і протиставляє remote:

"I don't use the word "remote" because it sets up the expectation that some people are essential and some aren't. I use the word "distributed" to describe what we do, where everyone is on an equal playing field [6].

Для того, щоб довести правильність своїх суджень, промовець вдається до стратегії переконання, впливаючи на емоційну сферу свідомості аудиторії, і ще раз виокремлює переваги віддаленої роботи:

- desire to give people autonomy over how they do their work;

- a distributed workforce is ideal for a technology company;

- there are so many apps and services that help with day-to-day communication, video conferencing, project management;

- give people the flexibility to make their own work environment [6].

Позаяк у сучасному світі доступність Інтернету є майже стовідсоткова, віддалена робота набуває все більшої популярності та попиту серед потенційних працівників. Наведені спікером переконливі аргументи відносять аналізовану промову до мотиваційного дискурсу. Мотивація тут спрямована на керівників, топ-менеджерів компаній, які міркують над залученням i збереженням талантів.

Суттєве місце на платформі TED, що цілком природно з огляду на екологічну ситуацію в світі, займає блок промов на тему "Environment". У виступі "What really happens to the plastic you throw away?”[1] Емма Брайс намагається проаналізувати, що насправді відбувається 3 пластиком, якщо ми його просто викинемо на сміттєзвалище. Авторка відповідає на це питання, простежуючи життєві цикли трьох пластикових пляшок, тим самим наголошуючи на небезпеці, якої одноразові товари завдають нашому світові. Щоб захопити увагу аудиторії, ораторка вдається до нестандартного представлення свого бачення проблеми і можливості ії розв'язати у формі анімаційного фільму.

Семантичне ядро промови “What really happens to the plastic you throw away?”

\begin{tabular}{|l|c|c|}
\hline \multicolumn{1}{|c|}{ Слово } & Кількість & Частота, \% \\
\hline plastic & 10 & 1.86 \\
\hline planet & 9 & 1.67 \\
\hline bottle & 8 & 1.48 \\
\hline eat & 4 & 0.74 \\
\hline make & 4 & 0.74 \\
\hline can & 4 & 0.74 \\
\hline where & 3 & 0.56 \\
\hline for & 3 & 0.56 \\
\hline million & 3 & 0.56 \\
\hline
\end{tabular}




\begin{tabular}{|l|l|l|}
\hline one & 3 & 0.56 \\
\hline piece & 3 & 0.56 \\
\hline plastics & 3 & 0.56 \\
\hline sea & 3 & 0.56 \\
\hline stream & 3 & 0.56 \\
\hline
\end{tabular}

Не дивно, що найчастотніше вживаними виявилися слова plastic, planet, bottle, адже авторка промови переймається долею планети, уявляючи, що стане, якщо іiі засмітити пластиковими пляшками. Модальним дієсловом can окреслюється можливе розгортання ситуації після того, як пляшка потрапляє на сміттєзвалище:

...Together, they create a harmful stew called leachate, which can move into groundwater, soil and streams, poisoning ecosystems and harming wildlife. It can take bottle one an agonizing 1,000 years to decompose [1], а лексемою eat прогнозується інша ситуація - після потрапляння пластику у водойми:

For example, it's eaten by lanternfish, the lanternfish are eaten by squid, the squid are eaten by tuna, and the tuna are eaten by us. And most plastics don't biodegrade, which means they're destined to break down into smaller and smaller pieces called micro plastics, which might rotate in the sea eternally [1].

Мотиваційний характер у цій промові створено за допомогою стратегії спонукання до дії. В анімаційному фільмі третя пляшка потрапляє на завод із переробки пластику:

A truck brings him to a plant where he and his companions are squeezed flat and compressed into a block. Okay, this sounds pretty bad, too, but hang in there. It gets better. The blocks are shredded into tiny pieces, which are washed and melted, so they become the raw materials that can be used again. As if by magic, bottle three is now ready to be reborn as something completely new [1].

Саме ця теза закликає людство до створення заводів із переробки пластику, оскільки тільки в такій концепції пластик не буде чинити шкідливий вплив на навколишнє середовище.

Висновки. Отже, мотивація як феномен, при якому діяльність однієї людини (чи групи людей) регулюється іншою, враховуючи ту чи ту потребу, є набором цілеспрямованих дій, пов'язаних $з$ інтенцією мовця вплинути на співрозмовника і в певний спосіб змінити або ж зберегти вже існуючий стан речей. Проаналізувавши три виступи спікерів на конференціях TED, беремося стверджувати, що вони є мотиваційними за своєю суттю. Виокремлення й аналіз семантичного ядра промов дозволяе переконатися в тому, що найуживаніші лексичні одиниці відображають тему виступу, спікер будує свою промову навколо єдиної ідеї, що і передбачено вимогами організаторів TED-конференцій. Виступи на конференціях TED носять інформативноперсуазивно-спонукальний характер, адже спікери послуговуються стратегіями інформування, переконання і спонукання, впливаючи відповідно на різні сфери свідомості: раціональне мислення, емоції та волевиявлення і тим самим творять мотиваційний дискурс.

Перспективність подальших досліджень вбачаємо в аналізі відеороликів промов на конференціях TED з позиції їхньої стратегічної організації: до яких стратегій і тактик вдаються оратори для здійснення мотиваційного впливу на аудиторію.

\section{References}

1. Bryce, Emma. What really happens to the plastic you throw away? https://www.ted.com/talks/emma_bryce_ what_really_happens_to the_plastic_you_throw_away/transcript

2. Collins, Anita. TED-Ed How playing an instrument benefits your brain. https://www.ted.com/talks/anita collins the benefits of music education

3. Kaysina, Daria. 2018. "Anhlomovnyi dyskurs ideatsiyi: stratehiyi komunikatyvnoho vplyvu (na materiali internet-platformy TED)". PhD diss., V. N. Karazin Kharkiv National University.

4. Klymchuk, Vitaliy. 2015. Motyvatsiynyi dyskurs osobystosti: na shlyakhu do sotsialnoyi psykholohiyi motyvatsiyi. Zhytomyr: Vyd-vo ZhDU imeni I. Franka.

5. Kryzhko, Olena. 2017. "Ponyattia motyvatsiyi u suchasniy linhvistychniy nautsi (slovotvirnyy, nominatyvnyy, linhvokohnityvnyy aspekty)". Visnyk Lvivskoho universytetu. Seriya : Filolohichna 64: 267-276.

6. Matt Mullenweg. Why working from home is good for business. https://www.ted.com/talks/matt_mullenweg why_working from home is_good_for_business

7. Oxford Learner's Dictionaries. https://www.oxfordlearnersdictionaries.com/ 
8. Pryshchak, Mykola and Larysa Matsko, Valentyna Hodlevska. 2009. Osnovy psykholohiyi ta pedahohiky. Vinnytsia. http://shron1.chtyvo.org.ua/Matsko Larysa/Osnovy psykholohii ta pedahohiky.pdf

9. Selivanova, Olena. 2006. Suchasna linhvistyka: terminolohichna entsyklopediya. Poltava: Dovkillia-K.

10. Slovnyk Ukrayinskoyi Movy. 2018. http://sum.in.ua/

11. Sullivan, Jeremiah. 1988. "Three roles of language in motivation theory". Academy of Management Review 13: 104-115. Accessed February 28, 2020. doi: 10.2307/258358.

12. Ted Ideas Worth Spreading. 2020. "How TED works". Accessed March 12. https://www.ted.com/about/ourorganization.

13. Vygotskiy, Lev. 1982. "Myshleniye i rech". Sobraniye sochineniy v 8 tomakh, T. 2. 53-61. Moskva: Pedagogika.

14. Zaniuk, Serhiy. 2001. Psykholohiya motyvatsii. Kyiv: Nika Tsentr.

Одарчук Наталия, Мирончук Татьяна. TED-конференции - платформа для англоязычного мотивационного дискурса. В последнее время TED-конференции стали одной из самых популярных платформ в мировом сообществе для распространения идей, достойных подражания. Произнесенные на английском языке речи, посвященные мотивации, занимают видное место среди многочисленных выступлений ученых, медиков, программистов, музыкантов, просто рядовых граждан, готовых поделиться идеей, достойной распространения. В статье подвергаются анализу выступления ораторов TED-конференций, чтобы довести их мотивационную направленность. Для реализации данной цели сначала истолковывается семантика понятия мотивации, а дальше на основе произвольно отобранных речей нескольких спикеров с платформы TED анализируется семантическое наполнение их текста. Для установления наиболее часто употребленных лексических единиц создается семантическое ядро каждого выступления. Выделение и анализ семантического ядра речей позволяет убедиться в том, что употребляемые лексические единицы отражают тему выступления, спикер строит свою речь вокруг единой идеи, что и предусмотрено требованиями организаторов TED-конференций.

Делается вывод о том, что мотивация как феномен, при котором деятельность одного человека (или группы людей) регулируется другой, учитывая ту или иную потребность, является набором целенаправленных действий, связанных с интенцией говорящего повлиять на собеседника и определенным образом изменить или сохранить уже существующее положение вещей. Выступления на конференциях TED имеют информативно-персуазивнопобудительный характер. С одной стороны, спикеру важно сообщить фактический материал (факты, идеи, результаты). Однако более важно для него - повлиять на слушателя, убедить в приемлемости своей идеи, вызвать эмоциональную рефлексию в аудитории, добиться того, чтобы выступление актуализировало проблему, вдохновило, смотивировало к дальнейшим действиям для ее решения. Осуществляя когнитивно-коммуникативную деятельность через TED talks с помощью стратегий информирования, убеждения и побуждения, выступающие влияют, соответственно, на различные сферы сознания: рациональное мышление, эмоции и волеизъявления. В результате этого они создают мотивационный дискурс, субъектами которого являются они сами в роли ораторов, и аудитория в роли реципиентов. лексема.

Ключевые слова: мотивация, мотивационный дискурс, TED-конференция, стратегия, семантическое ядро,

Odarchuk Natalia, Mironchuk Tetiana. TED-Conferences - the Platform for English Motivational Discourse. Recently, TED-conferences have become one of the most popular platforms in the global community for the dissemination of ideas worth sharing. Motivation speeches in English are at the forefront of numerous ones delivered by scientists, doctors, programmers, musicians, and ordinary citizens willing to share an idea worth spreading. The article analyzes the presentations of speakers at TED-conferences to bring their motivational focus. To achieve this goal, the semantics of the concept of motivation is first interpreted, and then, based on randomly selected presentations of several speakers from the TED platform, the semantic content of their text is analyzed. To establish the most frequently used lexical units, the semantic core of each speech is created. Singling out and the analysis of the semantic core of speeches allows us to make sure that the most commonly used lexical units reflect the topic of the speech, the speaker organizes his presentation around a single idea, which is provided for by the requirements of the TED-conferences organizers.

It is concluded that motivation as a phenomenon in which the activities of one person (or group of people) are regulated by another, taking into account some need, is a set of purposeful actions associated with the speaker's intention to influence the interlocutor and in a certain way change or maintain the already existing state of affairs. Speeches at TEDconferences are informative, persuasive and motivational in nature. On the one hand, it is important for the speaker to communicate factual material (facts, ideas, and results). However, what is more important for him is to influence the listener, to convince of the acceptability of his idea, to evoke emotional reflection in the audience, to ensure that the speech actualizes the problem, inspires, and motivates to further actions to solve it. Carrying out cognitive and communicative activities via TED talks with the help of strategies of information, persuasion and motivation, speakers influence different areas of consciousness - rational thinking, emotions and expression of will, respectively. As a result, they create a motivational discourse, the subjects of which they themselves are in the role of speakers, and the audience as recipients.

Key words: motivation, motivational discourse, TED-conference, strategy, semantic core, lexeme. 